enforce an academically high degree of purity involving artificially high cost of preparation without corresponding advantages in safety and therapeutic activity.

\section{A Pioneer of the Oil Engine}

As long as there are oil engines, there will be discussions as to the relative merits of the work of Herbert Akroyd Stuart in Great Britain and of Rudolph Diesel in Germany. Lesigners of engines to-day utilize the ideas of both, but whereas the name of Diesel has become a household word, that of Stuart is known only among engineers. It was said at the time Stuart died that he "belonged to that rather tragic fraternity of inventors whose achievements have not secured from the world at large the recognition they merited". That his work is fully appreciated in engineering circles was shown by the Diesel Engine Users' Association, which on January 11 held a luncheon at the Connaught Rooms, London, to commemorate the fiftieth anniversary of his most important patents.

After the luncheon, a sketch of Stuart's life and work was given in a paper by Mr. T. Hornbuckle and Mr. A. K. Bruce. Stuart was born in Yorkshire in 1864 and died in West Australia in 1927. He was among the earliest students of the Finsbury Technical College. While engaged at his father's engineering works at Fenny Stratford, Buckinghamshire, he began experimenting with internal combustion engines, and in the years 1886-92 took out nine British patents for improvements. His leading patents were No. 7146 of May 8, 1890, and No. 15994 of October 8, 1890. These were taken out in collaboration with C. R. Binney. In that of May 8, 1890, he claimed the novelty of compression ignition. Diesel's patent was not taken out until February 28, 1892. The manufacture of oil engines according to Stuart's patents was taken up by Messrs. Hornsby and Sons, Ltd., of Grantham, in 1891, and Stuart had little more to do with them. Unfortunately, the engines became known as "Hornsby-Akroyd" engines, and in America even as "Hornsby-Diesels". At his death, Stuart left instructions for his papers to be destroyed, but he bequeathed sums of $£ 500$ and $£ 700$ respectively to the Institution of Mechanical Engineers and the Institute of Marine Engineers for prizes for papers on oil engines.

\section{British and American Civil Engineers}

IN September last it had been arranged that representatives of the Institution of Civil Engineers should visit the United States in response to an invitation from the American Society of Civil Engineers, but international unrest in Europe resulted in the cancellation of that visit. Had the visit taken place, it was intended that Mr. W. J. E. Binnie, who was then president of the Institution, should present to the American Society of Civil Engineers a replica of the Myddelton Cup, as a token of the friendly relations which have existed between the two societies. Lord Lothian has now, however, on behalf of the Institution, handed the replica to
Colonel D. H. Sawyer, president of the American Society, at a gathering of the members of that Society held in Washington on January 9.

The original Cup was presented to Sir Hugh Myddelton in 1613 by the Worshipful Company of Goldsmiths of London for his services in providing London with a supply of potable water. It remained in the possession of the Myddelton family until 1922, when it was acquired by the Goldsmiths' Company. Lord Lothian has, by completing the ceremony of presentation, cemented the cordial feeling between the two societies and strengthened that part of the bond of international friendship which is based upon the creative genius of the civil engineer in all parts of the world.

\section{Non-Political Work of the League of Nations}

A REPont by the Secretary-General on the work of the League of Nations (July-mid-November, 1939), which has just been issued, is an immediate sequel to the regular report on the work of the League, 1938-39 ; but is the first of a series which will be published periodically to keep the States Members informed of the progress of the League's work (League of Nations. Report on the Work of the League (Continuation), July-mid-November, 1939. (Official No. A.6(a), 1939.) Pp. 62. (Geneva: League of Nations; London: George Allen and Unwin, Ltd., 1939.) 1s. 6d.). The report shows that with certain exceptions-the European Conference on Rural Life, which was to have met at Geneva in October, for example, had to be postponed sine die-the League has been able to carry on, in spite of the War, its essential activities in the non-political fields in which it has been responsible for so much successful and constructive work in recent years. For the development of international co-operation in economic and social affairs, the ereation of a Central Committee to direct and supervise the work of the League's Committees dealing with those questions has been recommended and a draft constitution submitted for the approval of the Assembly.

A section in the report on economic and financial questions refers to the meeting of representatives of National Nutrition Committees held at Buenos Aires in October and to measures taken to adapt the publications of the Economic Intelligence Service to the new conditions. Other sections deal with communications and transit, health questions, and traffic in opium and other dangerous drugs. It is interesting to note that maintenance of supervision of this traffic in war-time has been strongly urged by the United States of America, although not a member of the League.

\section{Vital Statistics of a Primitive People}

A STUDY of the vital statistics of the lowland Sěnoi (Sakai) of Perak, Malay Peninsula, by H. D. Noone (J. Fed. Malay States Mus., 15, $4 ; 1939$ ) is of interest in its bearing on the effect of the interracial and cultural contacts of a primitive people on their chances of survival. A generation ago it was regarded as a matter of time only before the then 